\title{
Rapid in Vitro multiplication protocol for ceropegia noorjahaniae Ans., a critically endangered, endemic plant of the Western Ghats
}

\begin{abstract}
Ceropegia noorjahaniae Ans. (Family: Asclepiadaceous) is one of the critically endangered, endemic plants growing in the grasslands of Western Ghats of India. Its tubers are edible and flowers have considerable ornamental value. Scarcity of pollinators and poor seed set are hurdles in the natural propagation of this plant, leading to a continuous depletion of its natural population. A rapid in vitro multiplication protocol has been developed to conserve this plant using axillary buds as propagules. Various media combinations have been tried for the induction of multiple shoots, their subsequent rooting and recovery of complete plants. Optimum response in terms of multiple shoot formation was achieved on MS medium supplemented with BA (2mg $\left.1^{-1}\right)$. In four weeks 10-12 shoots developed per axillary bud. Shoots were rooted on half strength MS + IBA $\left(2 \mathrm{mg} \mathrm{l}^{-1}\right)+$ NAA $\left(1 \mathrm{mg} \mathrm{l}^{1^{-1}}\right)+$ activated charcoal $\left(200 \mathrm{mg} \mathrm{l}^{-1}\right)$. Acclimatization of in vitro derived plants was accomplished by transfer to soilrite in paper cups and subsequently to soil. The developed protocol for in vitro propagation of this plant will significantly contributes towards its conservation.
\end{abstract}

Keywords: conservation, critically endangered, endemic, in vitro multiplication, MS medium
Volume 7 Issue 2 - 2017

\author{
Vinayak Kedage,' Simran Lilwani, ${ }^{2}$ Mayur \\ Kamble, ${ }^{3}$ Mansingraj Nimbalkar, ${ }^{4}$ Sandeep \\ $\mathrm{Pai}^{5}{ }^{5}$ Ghansham Dixit ${ }^{4}$ \\ 'Regenerative Medical Services Pvt Ltd, India. \\ ${ }^{2}$ Department of Biotechnology and Bioinformatics, Dr. DY Patil \\ University, India \\ ${ }^{3}$ Botanical Survey of India, India \\ ${ }^{4}$ Department of Botany, Shivaji University, India \\ ${ }^{5}$ Plant Biotechnology and Tissue Culture Division, Indian Council \\ of Medical Research, India
}

Correspondence: Vinayak Kedage, regenerative Medical Services Pvt Ltd. 22, Shah Industrial Estate, Nangargaon, Lonavala 41040 I (M.S.) India, Email vinayak.kedage@gmail.com
Abbreviations: BA, 6-benzyl amino purine; IAA, 3-inoleacetic acid; IBA, 3-indolebutyric acid; Kinetin, N-6 furfuryladenine; MS, murashige and skoog (1962) Medium; NAA, 1-nephthaleneacetic acid; TDZ, thiodiazuron

\section{Introduction}

Due to rapid depletion of forest and forest resources, many plant species are became endangered and are on the verge of extinction. Conservation of biodiversity is now a high priority area and needs special attention as far as environment is concerned. Conservation of plant genetic resources for food, fiber, fuel and pharmaceuticals is considered to be a major element of any strategy to achieve sustainable development of other natural resources. ${ }^{1}$ According to the World Bank document, India is one of the 12-mega diversity countries in the world, which collectively accounts for $70 \%$ of the world's biodiversity. ${ }^{2}$ Ceropegia noorjahaniae Ans. is a member of family Asclepiadaceous (Figure 1). It is one of the critically endangered, endemic plants of Maharashtra. ${ }^{3}$ The plant is well known for its peculiar flowers, which have high ornamental value and its edible tubers. The plant can easily be identified by its $2.7 \mathrm{~cm}$ long, glabrous corolla. Deforestation Western Ghats, Being endemic, scarcity of pollinators and poor seed set are the major causes in its dwindling numbers. The plant is found in its natural habitat in the Maharashtra, one of the states in India especially in few districts, and the extent of its occurrence is estimated to be less than $500 \mathrm{sq}$. $\mathrm{km}$. with severely fragmented populations. In 1996, only 19 mature individuals were located at Jarandeshwar hills of Satara district MS India. ${ }^{4}$ A typical habitat of this plant is found along ghat slopes in well-drained rocky-gravelly soil above 1000 meter altitude. The present investigations focused on in vitro propagation of Ceropegia noorjahaniae Ans. Through axillary bud multiplication and their acclimatization for restoration of this critically endangered plant species.

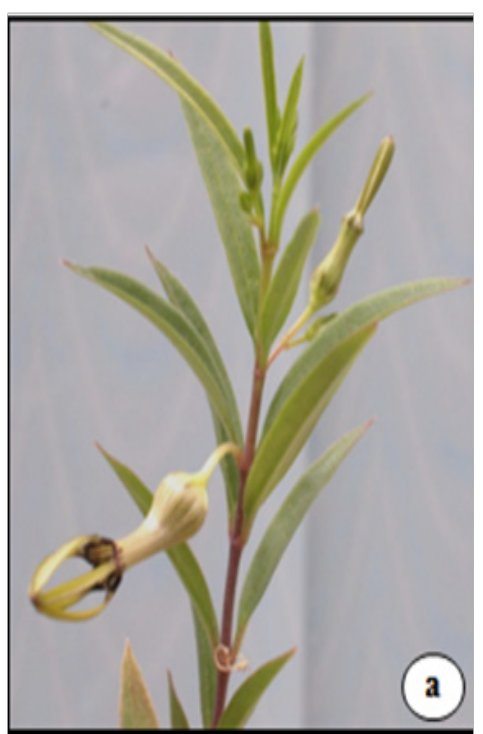

Figure I Habit of Ceropegia noorjahani Ans.

\section{Materials and methods}

Nodal segments of young $C$. noorjahaniae shoots were collected from mature plants grown in the botanical gardens of Shivaji University, Kolhapur, MS, India and used as explants. The explants were washed in running tap water for at least $30 \mathrm{~min}$ followed by a detergent, labolene $(5 \% \mathrm{v} / \mathrm{v})$ for $10 \mathrm{~min}$. followed by repeated washing in double distilled water. Surface sterilization of the explants was done with mercuric chloride $(0.1 \% \mathrm{w} / \mathrm{v})$ for $8 \mathrm{~min}$. and rinsed thoroughly (4-5times) with sterile double distilled water. Nodal explants $(1 \mathrm{~cm})$ were cultured on $\mathrm{MS}^{5}$ basal medium (major and min or salts, vitamins, 
FeEDTA, inositol and 170 $\mathrm{mg} \mathrm{l}^{-1}$ monobasic sodium phosphate) and supplemented with growth adjuvants such as BA, Kn, TDZ, NAA, IAA, IBA. Rooting of in vitro derived shoots was accomplished on half strength MS medium supplemented with various concentrations of auxins and activated charcoal $\left(200 \mathrm{mg}^{-1}\right)$. Sucrose $(3 \%, \mathrm{w} / \mathrm{v})$ was used as the carbon source and the $\mathrm{pH}$ of the media was adjusted to 5.8 prior to the addition of gelrite (Sigma, $0.2 \%$ ). All the media were autoclaved at $1.08 \mathrm{~kg} \mathrm{~cm}^{-2}$ for $20 \mathrm{~min}$. Cultures were maintained at $25 \pm 2^{\circ} \mathrm{C}$ with 16 -h light $/ 8$-h dark photoperiods (Philips TL 34, $25 \mu \mathrm{mol}$ $\left.\mathrm{m}^{-2} \mathrm{~s}^{-1}\right)$. All the experiments were repeated at least twice and data was collected after four weeks of culture. The effect of different treatment was quantified and the data was analyzed using one-way analysis of variance (ANOVA). Means were compared using Duncan's Multiple Range Analysis at 5\% level of significance.

\section{Results and discussions}

Multiple shoots were initiated from the nodal explants on all media combinations in four weeks (Table 1). The cytokinin, BA $\left(2 \mathrm{mg} \mathrm{l}^{-1}\right)$ was most potent for axillary bud initiation and proliferation resulting in $10.04 \pm 0.87$ shoots per axillary bud (Figure 2). However, the shoots were found to be delicate. Similar observations have been recorded in Ceropegia jainii and C. bulbosa, where BAP was found to be most effective (Patil, 1998). In contrast to this, multiple shoots produced on MS+BA $\left(2.0 \mathrm{mg} \mathrm{l}^{-1}\right)+\operatorname{IBA}\left(0.5 \mathrm{mg} \mathrm{l}^{-1}\right)$ produced shoots ( $7.54 \pm 0.83$ shoots per axillary bud) that were healthy and exhibited vigorous growth. A similar observation of a synergistic effect (on shoot multiplication) of BAP in combination with an auxin has been reported in many members of Asclepiadaceous such as Seshagiria sahyadrica ${ }^{6}$ Frerea indica Desai et al., ${ }^{1}$ Ceropegia candelabrum, ${ }^{7}$ Holostemma ada-kodien, ${ }^{8}$ Hemidesmus indicus ${ }^{9}$ and Holostemma annulare Sudha et al. ${ }^{10}$ In subsequent cultures too enhanced shoot multiplication was observed in our studies and this is in accordance with previous reports in other Asclepiadaceous members such as Ceropegia candelabrum Beena et al., ${ }^{7}$ Holostemma ada-kodien, ${ }^{8}$ Hemidesmus indicus ${ }^{9}$ and Gymnema sylvestre. ${ }^{11}$ Beena et al. ${ }^{7}$ have reported leaf and shoot tip abscission in micro propagated shoots of Ceropegia candelabrum. In our studies too when MS medium devoid of monobasic sodium phosphate shoot tip abscission occurred. It is speculated that accumulation of ethylene in the culture vessel could have been the cause of necrosis and abscission of the leaves and shoot tips as reported in Gymnema sylvestre and Hemidesmus indicus. ${ }^{11} \mathrm{~A}$ synergistic effect of monobasic sodium phosphate, $\mathrm{NH}_{4}^{+}$ions and cytokinin has been reported in grape for reduction of hyperhydricity in cultures. ${ }^{12}$

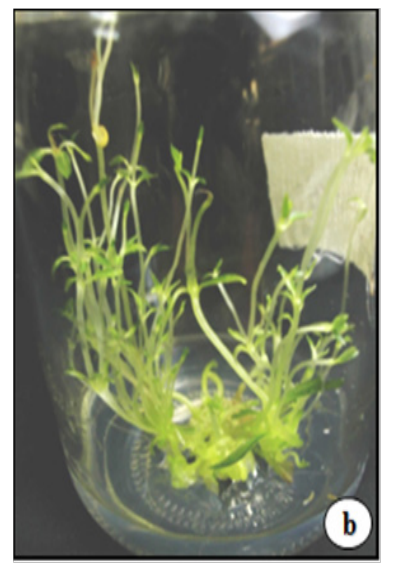

Figure 2 Multiple shoot induction on MS basal medium supplemented with BA $\left(2 \mathrm{mg} \mathrm{l}^{-1}\right)$.
Half strength MS (liquid) medium with activated charcoal (200mg $\left.\mathrm{1}^{-1}\right)$, IBA $\left(2 \mathrm{mg}^{-1}\right)$ and NAA $\left(1 \mathrm{mg} \mathrm{l}^{-1}\right)$ was found most effective in the induction of healthy roots ( $80 \%$ rooting; $2.63 \pm 0.38$ roots per shoot). This medium also supported robust shoot growth. (Table 2), (Figure $3)$. The roots on this medium were found to be thicker which has an added advantage during planting. It has been shown that combinations of two or more auxins are more effective in induction of roots in Syzygium cumini Yadav et al..$^{13}$ and Seshagiria sahyadrica Kedage et al. ${ }^{6}$ Effectiveness of IBA in root induction has been reported in Frerea indica Desai et al., ${ }^{1}$ Ceropegia candelabrum Beena et al., ${ }^{7}$ Holostemma ada-kodien, ${ }^{8}$ Hemidesmus indicus, ${ }^{9}$ Gymnema sylvestre ${ }^{11}$ and Tylophora indica. ${ }^{14}$ The beneficial effect of activated charcoal on rooting was well documented in Hemidesmus indicus, Mishra et al. ${ }^{15}$ and Seshagiria sahyadrica Kedage et al. ${ }^{6}$ and is similar to our finding in this study. Shoots, with well-developed roots were transferred to small plastic pots containing sterile soil rite for acclimatization (Figure 4). Plants were transferred subsequently to field conditions where they grew well and exhibited morphological characters similar to parent plants. The field-grown plants developed tubers and flowered normally. ${ }^{16,17}$ Shoot proliferation via axillary bud culture of selected individuals has great potential for micropropagation. Our studies in Ceropegia noorjahaniae are significant in the conservation of this critically endangered, endemic plant species.

Table I Response of MS basal medium supplemented with various growth hormones for multiple shoot induction in Ceropegia noorjahaniae Ans

\begin{tabular}{|c|c|c|}
\hline Sr. No. & $\begin{array}{l}\text { Medium with growth } \\
\text { hormones }\end{array}$ & Shoot number \pm SE \\
\hline $\mathrm{I}$. & MS - Basal & $0.79 \pm 0.10 \mathrm{a}$ \\
\hline 2. & $\mathrm{MS}+\mathrm{BA} 0.5 \mathrm{mg} \mathrm{l}^{-1}$ & $2.33 \pm 0.43 a$ \\
\hline 3. & $\mathrm{MS}+\mathrm{BA} \quad 1.0 \mathrm{mg} \mathrm{l}^{-1}$ & $5.54 \pm 0.62 c$ \\
\hline 4. & $\mathrm{MS}+\mathrm{BA} \quad 1.5 \mathrm{mg} \mathrm{l}^{-1}$ & $6.58 \pm 0.54 d$ \\
\hline 5. & $\mathrm{MS}+\mathrm{BA} 2.0 \mathrm{mg} \mathrm{l}^{-1}$ & $10.04 \pm 0.87 f$ \\
\hline 6. & $\mathrm{MS}+\mathrm{BA} 3.0 \mathrm{mg}^{-1}$ & $7.50 \pm 0.76 \mathrm{e}$ \\
\hline 7. & $\mathrm{MS}+$ Kinetin $0.5 \mathrm{mg} \mathrm{l}^{-1}$ & $1.17 \pm 0.44 \mathrm{a}$ \\
\hline 8. & MS+Kinetin $1.0 \mathrm{mg} \mathrm{I}^{-1}$ & $2.58 \pm 0.58 \mathrm{a}$ \\
\hline 9. & $\mathrm{MS}+$ Kinetin $2.0 \mathrm{mg} \mathrm{I}^{-1}$ & $2.17 \pm 0.59 \mathrm{a}$ \\
\hline 10. & $\mathrm{MS}+$ Kinetin $3.0 \mathrm{mg} \mathrm{l}^{-1}$ & $1.67 \pm 0.43 \mathrm{a}$ \\
\hline 11. & $\mathrm{MS}+\mathrm{TDZ} 0.5 \mathrm{mg} \mathrm{l}^{-1}$ & $3.67 \pm 0.56 \mathrm{~b}$ \\
\hline 12. & MS+TDZ $1.0 \mathrm{mg} \mathrm{l}^{-1}$ & $2.83 \pm 0.65 \mathrm{a}$ \\
\hline 13. & $\mathrm{MS}+\mathrm{BA} 2.0 \mathrm{mg}^{-1}+\mathrm{BA} \quad 0.5 \mathrm{mg} \mathrm{|}^{-1}$ & $7.54 \pm 0.83 \mathrm{e}$ \\
\hline 14. & $\mathrm{MS}+\mathrm{BA} 2.0 \mathrm{mg} \mathrm{l}^{-1}+$ Kinetin $2 \mathrm{mg} \mathrm{l}^{-1}$ & $2.08 \pm 0.62 a$ \\
\hline 15. & $\mathrm{MS}+\mathrm{BA} 2.0 \mathrm{mg} \mathrm{l}^{-1}+\mathrm{TDZ} 0.5 \mathrm{mg} \mathrm{l}^{-1}$ & $3.83 \pm 0.9 \mathrm{lb}$ \\
\hline
\end{tabular}

a. Observations were made after four weeks of culture.

b. Value represents means $\pm S E$ (standard error) of twelve replicates per treatment and all the experiments were repeated at least twice.

c. Means with the same letter are not significantly different at $5 \%$ level using Duncan's Multiple Range Test. 
Table 2 Response of in vitro rooting in Ceropegia noorjahaniae Ans. on half strength MS basal (liquid) medium supplemented with activated charcoal (200mg ${ }^{I^{-1}}$ ) and various auxins concentrations

\begin{tabular}{|c|c|c|c|}
\hline Sr. No & MS medium*+Auxins (mg l-1) & Rooted shoots (\%) & Root/shoot \pm SE \\
\hline I. & MS basal & 8 & $1.33 \pm 0.28 \mathrm{a}$ \\
\hline 2. & $\mathrm{MS}+\mid \mathrm{BA} 0.5 \mathrm{mg} \mathrm{|}^{-1}$ & 8 & $1.17 \pm 0.39 \mathrm{a}$ \\
\hline 3. & $\mathrm{MS}+\mid \mathrm{BA} \quad 1.0 \mathrm{mg} \mathrm{I}^{-1}$ & 16 & $1.50 \pm 0.50 \mathrm{a}$ \\
\hline 4. & $\mathrm{MS}+\mid \mathrm{BA} 2.0 \mathrm{mg} \mathrm{|}^{-1}$ & 40 & $2.25 \pm 0.7 \mathrm{lb}$ \\
\hline 5. & $\mathrm{MS}+\mid \mathrm{BA} 3.0 \mathrm{mg} \mathrm{|}^{-1}$ & 24 & $1.92 \pm 0.75 b$ \\
\hline 6. & $M S+\mid A A \quad 0.5 \mathrm{mg} \mathrm{I}^{-1}$ & 8 & $1.20 \pm 0.44 a$ \\
\hline 7. & $M S+\mid A A \quad 1.0 \mathrm{mg} \mathrm{I}^{-1}$ & 8 & $\mathrm{I} .25 \pm 0.4 \mathrm{Ia}$ \\
\hline 8. & $M S+I A A 2.0 \mathrm{mg} \mathrm{l}^{-1}$ & 12 & $1.83 \pm 0.59 b$ \\
\hline 9. & MS+IAA 3.0mg |-1 & 12 & $1.33 \pm 0.47 \mathrm{a}$ \\
\hline 10. & $\mathrm{MS}+\mathrm{NAA} 0.5 \mathrm{mg} \mathrm{l}^{-1}$ & 8 & $1.25 \pm 0.39 \mathrm{a}$ \\
\hline 11. & MS+NAA I.0mg l-1 & 12 & $\mathrm{I} .33 \pm 0.4 \mathrm{Ia}$ \\
\hline 12. & MS+NAA $2.0 \mathrm{mg} \mathrm{l}^{-1}$ & 16 & $1.75 \pm 0.39 b$ \\
\hline 13. & $\mathrm{MS}+\mathrm{NAA} 3.0 \mathrm{mg} \mathrm{I}^{-1}$ & 12 & $1.08 \pm 0.29 a$ \\
\hline 14. & $M S+|B A 2 m g|^{-1}+N A A|m g|^{-1}$ & 80 & $2.63 \pm 0.38 c$ \\
\hline 15. & $\mathrm{MS}+\mathrm{IBA} 2 \mathrm{mg} \mathrm{l}^{-1}+\mathrm{NAA} 2 \mathrm{mg} \mathrm{l}^{-1}$ & 50 & $2.00 \pm 0.37 b$ \\
\hline 16. & MS+IBA $\left.2 m g\right|^{-1}+\left.|A A| m g\right|^{-1}$ & 36 & $1.75 \pm 0.48 b$ \\
\hline 17. & $M S+|B A 2 m g|^{-1}+|A A 2 m g|^{-1}$ & 60 & $1.71 \pm 0.29 b$ \\
\hline
\end{tabular}

a. *Half strength MS Basal (Murashige and Skoog, 1962) medium supplemented with activated charcoal (200 $\left.\mathrm{mg} \mathrm{l}^{-1}\right)$.

b. Observations were made after four weeks of culture.

c. Value represents means $\pm S E$ (standard error) of twelve replicates per treatment and all the experiments were repeated at least twice.

d. Means with the same letter are not significantly different at $5 \%$ level using Duncan's Multiple Range Analysis.

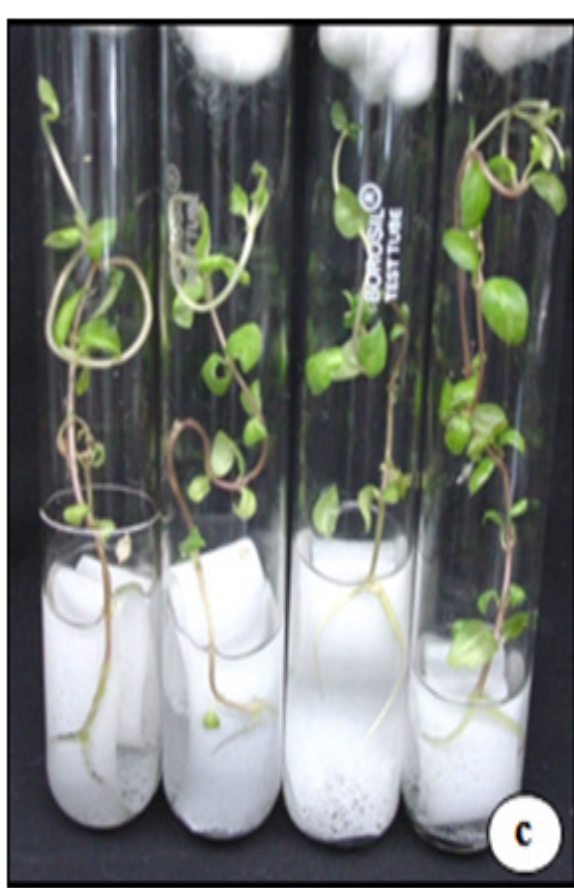

Figure 3 In vitro rooting on half strength MS basal medium supplemented with IBA $\left(2 \mathrm{mg} \mathrm{l}^{-1}\right)$ and NAA $\left(2 \mathrm{mg} \mathrm{l}^{-1}\right)$

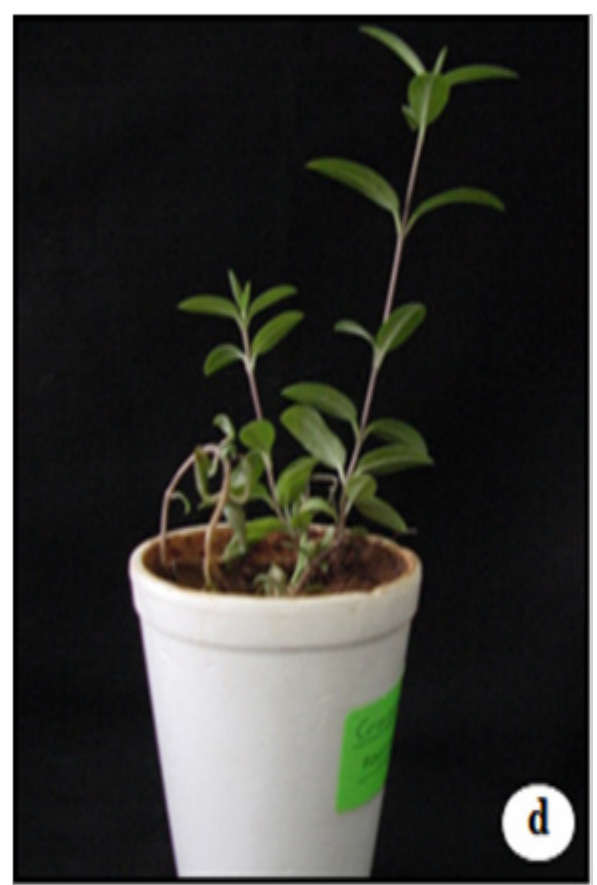

Figure 4 Hardened plant after one month. 


\section{Acknowledgements}

Authors are thankful to Head, Department of Botany and University authorities of Shivaji University, Kolhapur MS India for providing laboratory facility to carry out this research work.

\section{Conflict of interest}

The author declares no conflict of interest.

\section{References}

1. Desai NS, Suprasanna P, Bapat VA. Conservation status and in vitro multiplication of Frerea indica Dalz. An endemic and endangered plan from Western Ghats of Maharashtra. India Physiol Mol Biol Plants. 2003;9(2):265-268

2. World Bank; 2000.

3. Singh NP, Lakshminarsimhan P, Kartikeyan S, et al. Flora of Maharashtra State, Dicotyledons vol. II. Botanical Survey of India, Ministry of Environment and Forests. Govt. of India; 2001. 377 p.

4. Mishra DK, Singh NP. Endemic and Threatened Flowering plants of Maharashtra. Botanical Survey of India, Ministry of Environment and forests. Govt. of India; 2001. p. 142-143.

5. Murashige T, Skoog F. A revised medium for rapid growth and bioassays with tobacco tissue cultures. Physiol plant. 1962;15:473-497.

6. Kedage VV, Ghatge SR, Yadav SR, et al. Rescue of an endemic and vulnerable plant, Seshagiria sahyadrica Ans. and Hem. through micropropagation. Proc Nat Acad Sci India Sect B. 2009;79(3):262-266.

7. Beena MR, Martin KP, Kirti PB, et al. Rapid in vitro propagation of important Ceropegia candelabrum. Plant Cell Tissue and Organ Culture. 2003;72(3):285-289.
8. Martin KP. Rapid propagation of Holostemma ada-kodien Schult, a rare medicinal plant, thourgh axillary bud multiplication and indirect organogenesis. Plant Cell Reports. 2002;21(2):112-117.

9. Sreekumar S, Seeni S, Pushpagadan P. Micropropagation of Hemidesmus indicus for cultivation and production of 2-hydroxy 4-methoxy benzaldehyde. Plant Cell, Tissue and Organ Culture. 2000;62(3):211218 .

10. Sudha CG, Krishnan PN, Pushpangadan P. In vitro propagation of Holostemma annulare (Roxb.) K. Schum., a rare medicinal plant. In Vitro Cellular \& Developmental Biology - Plant. 1998;33(1):57-63.

11. Komalavalli N, Rao MV. In vitro micropropagation of Gymnema sylvestre - a multipurpose medicinal plant. Plant Cell, Tissue and Organ Culture. 2000;61:97-105.

12. Mhatre M, Salunkhe CK, Rao PS. Micropropagation of Vitis vinifera L: towards an improved protocol. Sci Hortic. 2000;84(3-4):357-363.

13. Yadav U, Lal Mm, Jaiswal VS. In vitro micropropagation of the tropical fruit tree syzygium cuminii L. Plant Cell, Tissue and Organ Culture. 1990;21(1):87-92.

14. Faisal M, Anis M. Rapid mass propagation of Tylophora indica Merrill via leaf callus culture. Plant Cell, Tissue and Organ Culture. 2003;75(2):125-129.

15. Mishra N, Mishra P, Datta SK, et al. Improvement of clonal propagation of Hemidesmus indicus R. Br. through adenine sulphate. J Plant Biotechnology. 2003;5:239-244.

16. Patil VM. Micropropogation studies in Ceropegia species. In vitro Cell Dev Biol Plant. 1998;34(3):240-243.

17. Patnaik J, Debata BK. Micropropagation of Hemidesmus indicus (L.) R. Br. through axillary bud culture. Plant Cell Rep. 1996;15(6):427-430. 